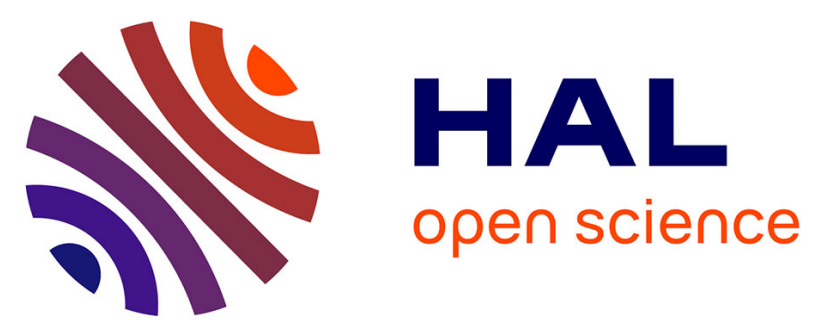

\title{
Post-seismic permeability change in a shallow fractured aquifer following a M-L 5.1 earthquake (Fourbanne karst aquifer, Jura outermost thrust unit, eastern France)
}

\author{
A. Charmoille, O. Fabbri, J. Mudry, Y. Guglielmi, C. Bertrand
}

\section{- To cite this version:}

A. Charmoille, O. Fabbri, J. Mudry, Y. Guglielmi, C. Bertrand. Post-seismic permeability change in a shallow fractured aquifer following a M-L 5.1 earthquake (Fourbanne karst aquifer, Jura outermost thrust unit, eastern France). Geophysical Research Letters, 2005, 32, pp.L18406. 10.1029/2005GL023859 . hal-00407426

\section{HAL Id: hal-00407426 \\ https://hal.science/hal-00407426}

Submitted on 19 Feb 2021

HAL is a multi-disciplinary open access archive for the deposit and dissemination of scientific research documents, whether they are published or not. The documents may come from teaching and research institutions in France or abroad, or from public or private research centers.
L'archive ouverte pluridisciplinaire HAL, est destinée au dépôt et à la diffusion de documents scientifiques de niveau recherche, publiés ou non, émanant des établissements d'enseignement et de recherche français ou étrangers, des laboratoires publics ou privés. 


\title{
Post-seismic permeability change in a shallow fractured aquifer following a $M_{L} 5.1$ earthquake (Fourbanne karst aquifer, Jura outermost thrust unit, eastern France)
}

\author{
A. Charmoille, ${ }^{1}$ O. Fabbri, ${ }^{1}{ }^{\text {J. Mudry, }}{ }^{1}$ Y. Guglielmi, ${ }^{2}$ and C. Bertrand ${ }^{1}$ \\ Received 20 June 2005; revised 26 July 2005; accepted 18 August 2005; published 27 September 2005.
}

[1] Following a $\mathrm{M}_{\mathrm{L}} 5.1$ earthquake in eastern France, a post-seismic 12-day long electrical conductivity increase was recorded in the water discharging from a karst aquifer located $3 \mathrm{~km}$ from the epicentre. We attribute this to a permeability enhancement which allowed long-residence time water from low-permeability fractures located in the saturated zone to be expelled. The permeability enhancement shows that shallow aquifers can be significantly deformed for several days by moderate magnitude earthquakes. Citation: Charmoille, A., O. Fabbri, J. Mudry, Y. Guglielmi, and C. Bertrand (2005), Post-seismic permeability change in a shallow fractured aquifer following a $\mathrm{M}_{\mathrm{L}} 5.1$ earthquake (Fourbanne karst aquifer, Jura outermost thrust unit, eastern France), Geophys. Res. Lett., 32, L18406, doi:10.1029/ 2005 GL023859.

\section{Introduction}

[2] Hydrological responses to earthquakes mainly concern events of moment tensor magnitudes larger than 6 [Muir-Wood and King, 1993; Rojstaczer et al., 1995; Wang et al., 2004]. The pre-, co- and post-seismic responses to moderate magnitude ( 3 to 6 ) earthquakes reflect water motion from deep (>100 m), possibly hydrothermal, aquifers [Toutain et al., 1997; Léonardi et al., 1998; Favara et al., 2001]. To explain post-seismic water releases in fractured aquifers, three models have been proposed: The fault valving model [Sibson, 1990] consists of a co-seismic rupture of an impervious barrier sealing an overpressured aquifer. Water release can also be the consequence of a permeability increase following co-seismic formation or reactivation of fractures [Rojstaczer et al., 1995; Tokunaga, 1999] or as the result of co-seismic elastic strain release [Muir-Wood and King, 1993; Roeloffs et al., 2003; Wang et al., 2004].

[3] The aim of this contribution is to show that coand post-seismic strain can be detected by groundwater chemical monitoring. This objective is achieved by analysing the effects of a small magnitude earthquake $\left(\mathrm{M}_{\mathrm{L}} 5.1\right.$, http://renass.u-strasbg.fr) on a shallow aquifer not connected to deep aquifers. The earthquake occurred on 23/02/04 at $20 \mathrm{~km} \mathrm{NE}$ of the city of Besançon, eastern France, in a low seismicity zone (Figure 1). Epicenter location is $47.3^{\circ} \mathrm{N}-6.3^{\circ} \mathrm{E}$. The observed post-seismic signal

\footnotetext{
${ }^{1}$ Laboratoire de Géosciences, EA 2642, Université de Franche-Comté, Besançon, France.

${ }^{2}$ UMR 6526, CNRS/UNSA, Valbonne, France.
}

Copyright 2005 by the American Geophysical Union. 0094-8276/05/2005GL023859 consisted of a 12-day long groundwater electrical conductivity (EC) increase.

\section{The Fourbanne Aquifer: Structure and Hydrogeology}

[4] The Fourbanne aquifer consists of $70 \mathrm{~m}$ thick Middle Jurassic fractured and karstified permeable limestones which overly $100 \mathrm{~m}$ thick Lower Jurassic impervious marls. The aquifer is bounded by two thrust faults: the Ognon thrust and the Doubs thrust (Figure 1) and its recharge area is $37 \mathrm{~km}^{2}$. The Fourbanne spring which is the sole discharge location of the aquifer is located near the Doubs thrust at $3 \mathrm{~km}$ from the earthquake epicenter. A geometric construction based on the epicenter location, the focal depth, and the available focal solutions (http://renass.u-strasbg.fr) shows that the earthquake fault might merge with the Ognon thrust fault which bounds the Fourbanne aquifer to the NW (Figure 1).

[5] For three years, elevation, temperature and $\mathrm{EC}$ of water in an underground stream have been recorded every $15 \mathrm{mn}$ by pressure gages at two points of the Fourbanne aquifer. The first point (Fontenotte station, Figure 1) is located in a natural karst conduit $30 \mathrm{~m}$ below the Earth surface, in the vadose zone, at the low-water level of the saturated zone (SZ), and was chosen to measure the recharge to the SZ. A few meters downstream of this measurement point, the conduit enters the SZ. The second monitoring point is located at the discharge location of the SZ (Fourbanne spring, Figure 1) and was chosen to characterize both infiltration and SZ transient effect on the physical parameters at the Fourbanne discharge location. Geological cross-sections show that the lower boundary of the aquifer (top of impervious marls) is $50 \mathrm{~m}$ lower at Fourbanne than at Fontenotte. It ensues that the thickness of the SZ downstream of Fontenotte is larger than at Fontenotte station or upstream of it.

[6] The response of the Fourbanne aquifer to hydrometeorological fluctuations is typical of a double-permeability carbonate aquifer, with highly permeable karstified fractures characterized by centimetric to metric apertures, and low-permeability (LP) fractures, with apertures less than one millimetre [Guglielmi and Mudry, 2001]. This permeability heterogeneity influences residence time of water and water/rock interactions. In karst aquifers, water EC depends mainly on the $\mathrm{HCO}_{3}^{-}$concentration. Waters flowing from the LP fractures, inside which water has a long residence time, are characterized by high $\mathrm{EC}$ values (resulting from $\mathrm{HCO}_{3}^{-}$content increase) and high $\mathrm{Mg}^{2+}$ concentrations, according to the slow dissolution kinetics of dolomite [Celle-Jeanton et al., 2003]. Thus, an increase in 


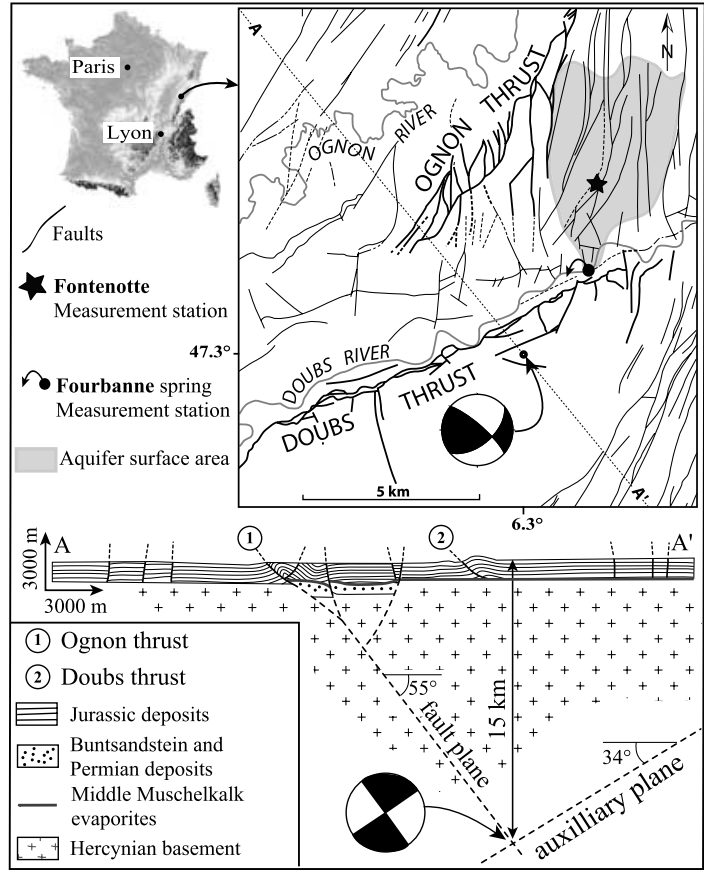

Figure 1. Geological setting of the study area.

$\mathrm{Mg}^{2+}$ concentration or EC of the Fourbanne spring water reflects the outflow of a long residence time water. The Fourbanne spring flowrate $\left(Q_{S}\right)$ is due partly to water coming from LP fractures $\left(Q_{L}\right)$ and partly to water coming from permeable fractures $\left(Q_{P}\right)$ :

$$
Q_{S}=Q_{P}+Q_{L}
$$

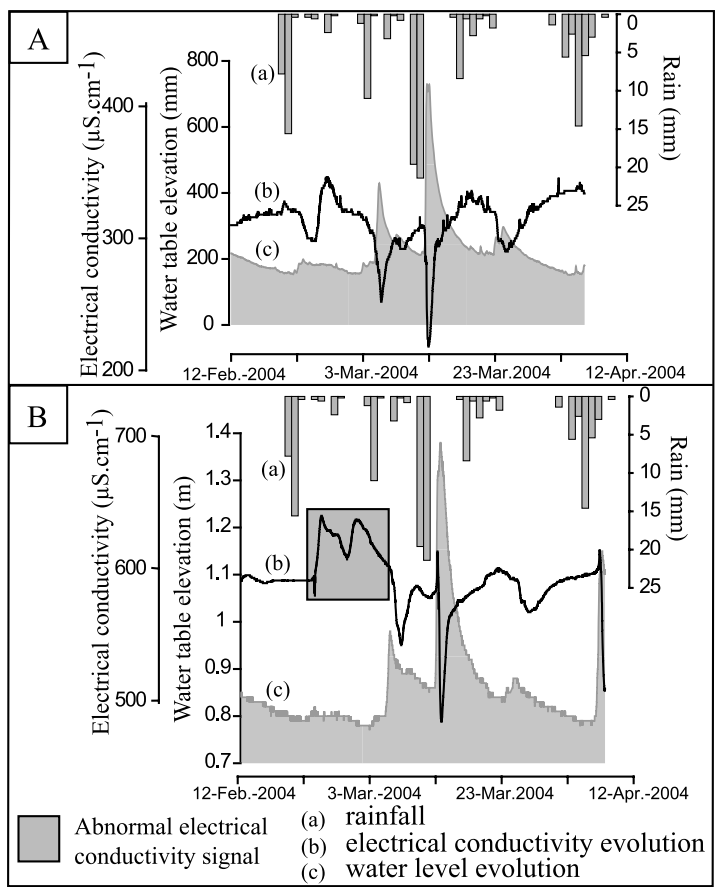

Figure 2. (a) Water table, rainfall, and EC records at Fontenotte station (vadose zone). (b) Water table, rainfall, and EC and records at Fourbanne station (saturated zone).

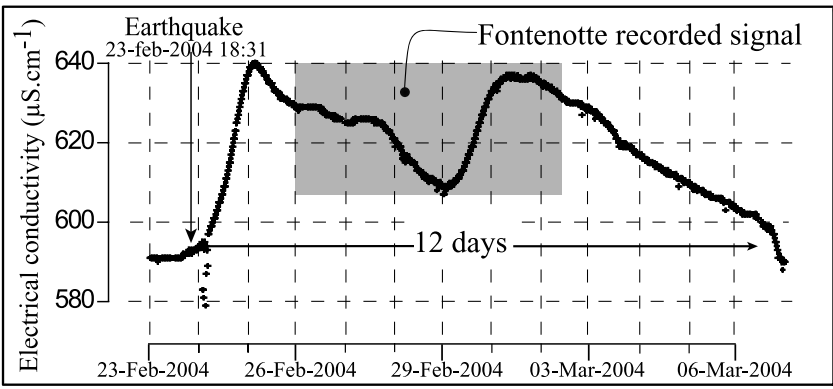

Figure 3. Detail of the post-seismic EC variations versus time.

Proportions depend on the hydro-meteorological conditions. During a low-water period, the water EC and the $\mathrm{Mg}^{2+}$ and $\mathrm{HCO}_{3}^{-}$concentrations measured at the Fourbanne spring increase. This reflects a relative increase of the LP fractures contribution to the SZ.

\section{Post-Seismic Anomalous Electrical Conductivity}

[7] At the Fontenotte station (Figure 2a), during the $12 / 02 / 04-01 / 03 / 04$ time interval, the measurement device recorded infiltration transient induced by snowmelt and rain $(7.8 \pm 0.1 \mathrm{~mm}$ on the $21 / 02 / 04$ and $15.6 \pm 0.1 \mathrm{~mm}$ on the $22 / 02 / 04)$. The dilution produced by this recharge began on the 23/02/04 and was suddenly interrupted, as shown by the EC increase of $42 \mu \mathrm{S} / \mathrm{cm} \pm 1 \mu \mathrm{S} / \mathrm{cm}$, which lasted until the 26/02/04. At the Fourbanne station (Figures $2 \mathrm{~b}$ and 3 ), during the same time interval, a significant increase of the water mineralization was recorded and reached $640 \pm 1 \mu \mathrm{S} / \mathrm{cm}$. It occurred seven hours after the earthquake and lasted for 12 days. This signal can be divided in three parts (Figure 3): a EC increase of $3 \pm 1 \mu \mathrm{S} / \mathrm{cm}$ per hour for twelve hours, followed from the $26 / 02 / 04$ to the $03 / 03 / 04$ by a dilution and an EC increase which occurred coevally with the EC signal recorded at the Fontenotte station, and a slow return to the initial value until the end of the signal (Figure 3). During this period, the water table fluctuated only by a few centimetres and it is not possible to differentiate the earthquake effect from the 21/02 and 22/02 infiltration effects (Figure 2b). The water temperature at the Fourbanne spring did not show any variation.

\section{Hydrogeological Significance of the Post-Seismic Signal}

[8] After the 23/02/04 earthquake, the EC at the Fourbanne spring increased by $50 \mu \mathrm{S} / \mathrm{cm}$, and returned to its pre-earthquake value 12 days later. In normal hydrologic conditions, the EC time history at Fourbanne reflects, with some delay and some distortion, the EC history at Fontenotte. But after the earthquake, the two records differed significantly. The passage of water across the SZ induced an abnormal increase of the EC (detected at Fourbanne), reflecting a mineralization excess which cannot be explained by classical hydrogeological interpretations. Indeed, at Fourbanne, significant and durable EC increases cannot be accounted for by rainfall or snowmelt. Similarly, 
Table 1. Calculation of the Water Excess Outflow From LowPermeability Fractures

\begin{tabular}{lcc}
\hline & Volume, $\mathrm{m}^{3}$ & Error, \% \\
\hline$\left(\mathrm{V}_{\mathrm{S}}\right)$ total outflow & $30.10^{3}$ & \pm 5 \\
$\quad$ water volume at spring & & \\
$\quad(12$ days after earthquake $)$ & $18.10^{3}$ & \pm 20 \\
$\left(\mathrm{~V}_{\mathrm{L}}\right)$ & $13,8.10^{3}$ & \pm 5 \\
$\left(\mathrm{~V}_{\text {LTH }}\right)$ & $\mathbf{4 , 3 . 1 0 ^ { 3 }}$ & \pm 25 \\
$\left(\mathbf{V}_{\text {Ex }}\right)$ & $6,1.10^{5}$ & \pm 25 \\
Minimum affected saturated rock & & \\
\hline
\end{tabular}

the arrival of deep waters can be ruled out because of the lack of any temperature increase. The earthquake thus appears to have caused a mobilisation, in the SZ, of water with a longresidence time. The same phenomenon can be invoked to explain the $42 \mu \mathrm{S} / \mathrm{cm}$ EC increase recorded at Fontenotte. However, the EC increase as well as the duration are smaller. These contrasts are likely due to the fact that, at the level of the measuring point, the conduit lies in the vadose zone overlying a thin SZ whose contribution to the underground stream alimentation is weak. By using the following flux equations, water excess volume originating in the saturated LP fractures can be quantified:

$$
\begin{aligned}
& Q_{L}=Q_{S} \times\left[\left(X_{S}-X_{P}\right) /\left(X_{L}-X_{P}\right)\right] \\
& Q_{P}=Q_{S} \times\left[\left(X_{L}-X_{S}\right) /\left(X_{L}-X_{P}\right)\right]
\end{aligned}
$$

where $X_{S}, X_{P}$ and $X_{L}$ represent respectively the water $\mathrm{EC}$ at the spring, in highly permeable fractures, and in low permeability fractures. The flowrate $\left(Q_{S}\right)$ at the spring during the earthquake is $30 \mathrm{l} / \mathrm{s}$. It remained constant, as indicated by the negligible variations of the water level during the period considered. An average value of $700 \mu \mathrm{S} / \mathrm{cm}$ deduced from previous field experiments, is assigned to $X_{L}$. The $400 \mu \mathrm{S} / \mathrm{cm}$ value of $X_{P}$ is the average of the EC measured in the underground river flowing in the unsaturated zone.

[9] Equations (2) and (3) give instantaneous flowrates $Q_{L}$ and $Q_{P}$. Integration through time of $Q_{L}$ and $Q_{P}$ give the respective volumes of the waters flowing out from the LP fractures $\left(V_{L}\right)$ and the permeable fractures $\left(V_{P}\right)$ during the considered 12 days (Table 1). The subtraction of the theoretical volumes $\left(V_{L T H}\right)$ of water coming from the LP fractures, and which would have flowed at the spring without any earthquake, from the previously calculated volume of water flowing from the LP fractures $\left(V_{L}\right)$ gives an excess of water volume $\left(V_{E X}\right)$ of $4,3.10^{3} \mathrm{~m}^{3}$ which flowed during the 12 days of EC increase (Table 1). Waters are oversaturated in $\mathrm{HCO}_{3}^{-}$and $\mathrm{Ca}^{2+}$ with respect to calcite, so precipitation of this mineral can occur. The calculated volume of the water excess is thus underestimated. With an effective porosity of a karst aquifer comprised between $0.7 \%$ and $1 \%$ [Jeannin and Grasso, 1995], the corresponding saturated rock volume can be estimated at $6,1.10^{5} \mathrm{~m}^{3}$ (Table 1).

\section{Discussion of the Possible Mechanisms}

[10] The earthquake seismic waves induced an elastic deformation of the Earth surface, as testified by records of a seismometer located $24 \mathrm{~km}$ far from Fourbanne. Deformation values recorded in the N-S, E-W and $\mathrm{Z}$ directions are comprised between 0.1 and $0.4 \mathrm{~mm}$ (http://geoazur. unice.fr). The LP fracture hydraulic apertures are of the same order of magnitude as the co-seismic deformation. Therefore, the deformation of the LP fracture planes could be the cause of permeability variations. In contrast, the effect of the co-seismic deformation will go undetected when affecting the permeable fractures with centimetric to metric apertures.

[11] Gaffet et al. [2003] showed a water flow acceleration following an earthquake whose epicenter was located $6250 \mathrm{~km}$ far away. This flow acceleration was detected by magnetic measurements in a low-noise laboratory located underground in a karst aquifer. This shows that, despite large distances between the epicenter and the aquifer, the seismic waves can induce flow changes by a transient deformation of the aquifer. Similarly, Husen et al. [2004] demonstrated that geyser frequencies can be deteriorated by large-magnitude earthquakes at distances larger than $3000 \mathrm{~km}$. The Fourbanne aquifer is close to the epicenter, so seismic waves can induce flow changes in the Fourbanne aquifer. Figure 4 gives an explanation of the formation of the post-seismic signal after the propagation of the seismic wave. Before the earthquake, the water level and the EC are constant in the karst conduit. Water which flows in the karst conduits is less mineralized than water contained in LP fractures (Figure 4). During the earthquake, the seismic waves induce an oscillation of the water table. This oscillation could not be recorded because

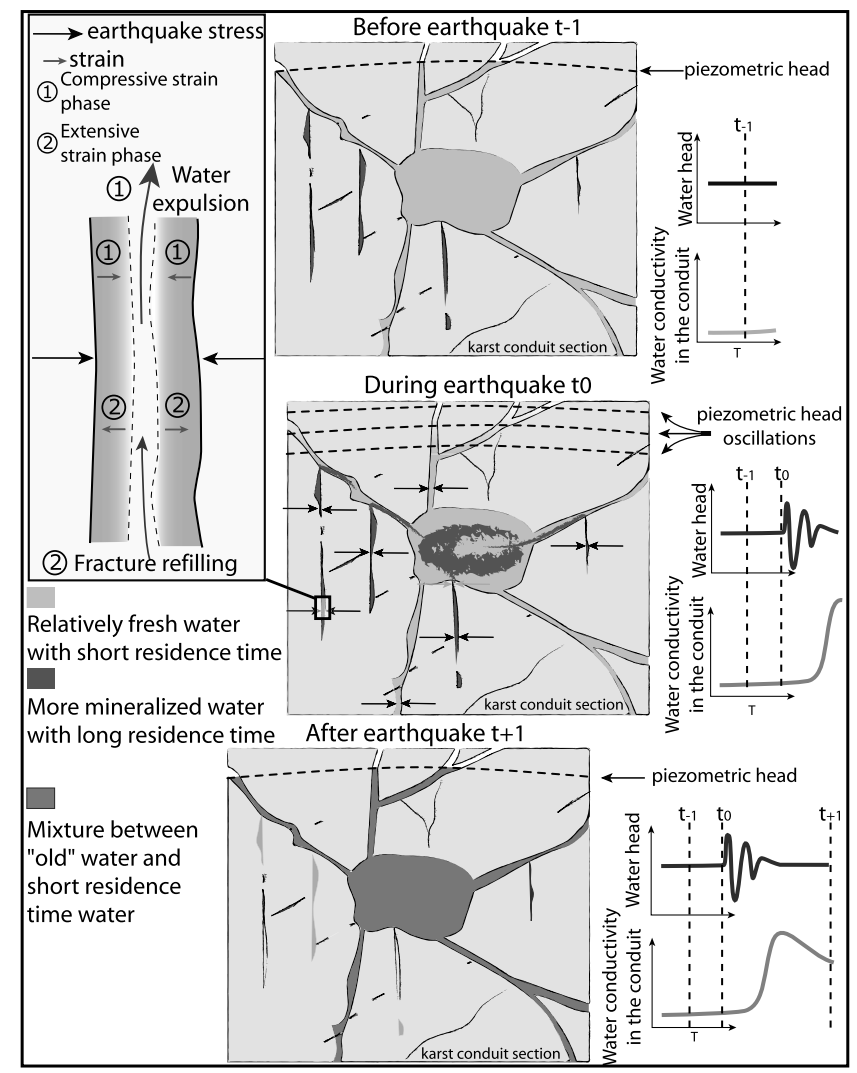

Figure 4. Model of the effect of a seismic wave on a karst aquifer. 
of a too loose measurement rate. The stresses acting on the rock mass will cause an elastic deformation of fracture planes. "Old water" contained in LP fractures is expelled. This induces an EC increase in the permeable conduits. Due to the saturated status of this part of the aquifer, expelled water is immediately replaced by new, less mineralized, water. After the waves have crossed the aquifer, the water table returns to its initial level. Then the water volume which flows in the conduit is a mixture between a larger part of "old water" than before the earthquake and water coming from the permeable area (Figure 4).

[12] However, permeability changes caused by elastic fracture deformation linked with the propagation of the seismic waves are typically a short-lived mechanism. In consequence, arrival at the spring of expelled water will not last for more than 48 hours, due to the hydraulic characteristics of the Fourbanne aquifer, as determined by several tracing tests. This does not agree with the 12-day duration of the post-seismic signal, which requires a durable permeability change. The passage of the seismic waves could have indirectly contributed to a several-day long permeability change by inducing the formation of new fractures which would have enhanced the permeability of LP fractures [Rojstaczer et al., 1995]. Such a scenario, which requires that the new fractures form a connected network, can be ruled out in the present case. Indeed, the Besançon earthquake did not cause any surface rupture. Moreover, the distance between the hypocentre and the karst area is $17 \mathrm{~km}$. At such a distance, the deformation induced by a $\mathrm{M}_{\mathrm{L}} 5.1$ earthquake remains in the elastic domain during the seismic wave passage [Kennett, 1983]. Fracture formation is restricted to the hypocentral area, that is in a volume of about $1 \mathrm{~km}^{3}$ centered on the hypocenter [Scholz, 2002]. Fault valving by breach of the impervious Jurassic marls [Sibson, 1990] can be discarded: Indeed, the marl layers are too remote from the hypocenter. Moreover, the EC increase would have been far more important than what is observed, given the existence of salt or gypsum deposits below the marls.

[13] Muir-Wood and King [1993] showed that the coseismic elastic strain model can explain various post-seismic hydrological signatures. They suggested that, depending on their attitudes, pre-existing fractures will open or close in response to strain associated with the earthquake cycle. This scenario can be applied to the Fourbanne aquifer. During the interseismic period, water is stored in the LP fractures. At the time of the earthquake, the water flows out by permeability enhancement of LP fractures caused by strain release, until the strain is totally released. It should be underlined that the eventual return of the EC to its preearthquake value does not imply that the permeability of the LP fractures has returned to its pre-earthquake value. Indeed "old water" could have been replaced by new, poorly mineralized, water. The coseismic elastic strain model explains well the fact that the EC variation lasts for more than 12 days. Unlike the Muir-Wood and King [1993] model, deep waters do not play any role in the present case because of an impervious lower boundary of the aquifer. If this model can be applied to the Fourbanne aquifer, it follows that the minimum theoretical volume of crust affected by this permanent strain is about $250 \mathrm{~km}^{3}$, given the distance hypocenter-aquifer and the surface area of the aquifer. This estimate falls within the range value of $10^{2}-10^{3} \mathrm{~km}^{3}$ proposed by Muir-Wood and King [1993].

\section{Conclusion}

[14] Following the 23/02/04 Besançon earthquake, a post-seismic mineralization increase was detected in the water flowing out of the Fourbanne aquifer. This chemical variation is interpreted as the result of a permeability enhancement of a set of low-permeability fractures which yielded a minimum water volume excess of $4300 \mathrm{~m}^{3}$ for 12 days. This shows that a moderate magnitude earthquake can have detectable effects in a near-surface aquifer and confirms the Muir-Wood and King [1993] hypothesis that "even small events should modify hydrogeological conditions". Despite the large distance between the aquifer and the hypocenter, the coseismic strain model explains well the recorded signal, according to the hydraulic characteristics of the Fourbanne karst aquifer. The record of groundwater electrical conductivity is a very sensitive tool, even in low seismicity areas. Without this parameter, no post-seismic signal would have been detected at the Fourbanne spring. In the absence of large water volume release, water chemical characteristics improve the detection threshold of post-seismic strain. As suggested by Wang et al. [2004], physical and chemical monitoring can provide reliable data to check the validity of models currently proposed to explain large water releases following earthquakes.

[15] Acknowledgment. Dr. Mettetal of the DIREN Franche-Comte provided financial support for the study.

\section{References}

Celle-Jeanton, H., C. Emblanch, J. Mudry, and A. Charmoille (2003), Contribution of time tracers $\left(\mathrm{Mg}^{2+}, \mathrm{TOC}, \delta^{13} \mathrm{C}_{\mathrm{TDIC}}, \mathrm{NO}_{3}^{-}\right)$to understand the role of the unsaturated zone: A case study-Karst aquifers in the Doubs valley, eastern France, Geophys. Res. Lett., 30(6), 1322, doi:10.1029/2002GL016781.

Favara, R., F. Grassa, S. Inguaggiato, and M. Valenza (2001), Hydrogeochemistry and stable isotopes of thermal springs: Earthquake-related chemical changes along Belice Fault (Western Sicily), Appl. Geochem., 16, $1-17$.

Gaffet, S., Y. Guglielmi, J. Virieux, G. Waysand, A. Chawala, R. Stolz, C. Emblanch, M. Auguste, D. Boyer, and A. Cavaillou (2003), Simultaneous seismic and magnetic measurements in Low-Noise Underground Laboratory (LSBB) of Rustrel, France, during the 2001 January Indian earthquake, Geophys. J. Int., 155, 981-990.

Guglielmi, Y., and J. Mudry (2001), Quantitative measurement of channelblock hydraulic interaction by experimental saturation of a large, natural, fissured rock mass, Groundwater, 39, 696-701.

Husen, S., R. Taylor, R. B. Smith, and H. Healser (2004), Changes in geyser eruption behavior and remotely triggered seismicity in Yellowstone Park produced by the 2002 M 7.9 Denali fault earthquake, Alaska, Geology, 32, 537-540

Jeannin, P., and A. D. Grasso (1995), Recharge respective des volumes de roche peu perméable et des conduits karstiques, rôle de l'épikarst, Bull. Hydrogeol., 14, 95-111.

Kennett, B. L. N. (1983), Seismic Wave Propagation in Stratified Media, 339 pp., Cambridge Univ. Press, New York.

Léonardi, V., F. Arthaud, A. Tovmassian, and A. S. Karakhanian (1998), Relationships between seismic activity and piezometric level changes in the Arax basin (SW Armenia): Attempt of a typology of seismically induced piezometric anomalies, Tectonophysics, 273, 293-316.

Muir-Wood, R., and G. King (1993), Hydrological signatures of earthquake strain, J. Geophys. Res., 98, 22,035-22,068.

Roeloffs, E., M. Sneed, D. L. Galloway, M. L. Sorey, C. D. Farrar, J. F. Howle, and J. Hughes (2003), Water-level changes induced by local and distant earthquakes at Long Valley caldera, California, J. Volcanol. Geotherm. Res., 127, 269-303. 
Rojstaczer, S., S. Wolf, and R. Michel (1995), Permeability enhancement in the shallow crust as a cause of earthquake-induced hydrological changes, Nature, 373, 237-239.

Scholz, C. H. (2002), The Mechanics of Earthquakes and Faulting, 2nd ed. 496 pp., Cambridge Univ. Press, New York.

Sibson, R. H. (1990), Rupture nucleation on unfavourably oriented faults, Bull. Seismol. Soc. Am., 80, 1580-1604.

Tokunaga, T. (1999), Modeling of earthquake-induced hydrological changes and possible permeability enhancement due to the 17 January 1995 Kobe Earthquake, Japan, J. Hydrol., 223, 221-229.

Toutain, J. P., M. Munoz, F. Poitrasson, and A. C. Lienard (1997), Springwater chloride ion anomaly prior to $\mathrm{a}_{\mathrm{L}}=5.2$ Pyrenean earthquake, Earth Planet. Sci. Lett., 149, 113-119.
Wang, C. Y., C. H. Wang, and M. Manga (2004), Coseismic release of water from mountains: Evidence from the $1999\left(\mathrm{M}_{\mathrm{w}}=7.5\right)$ Chi-Chi, Taiwan, earthquake, Geology, 32, 769-772.

C. Bertrand, A. Charmoille, O. Fabbri, and J. Mudry, Laboratoire de Géosciences, EA 2642, Université de Franche-Comté, 16 route de Gray, F-25030 Besançon, France. (arnaud.charmoille@univ-fcomte.fr)

Y. Guglielmi, UMR 6526, CNRS/UNSA, 250 rue A. Einstein, F-06560, Valbonne, France. 